\title{
IMPLEMENTATION OF COMMUNITY DEVELOPMENT AND KNOWLEDGE SHARING IN IMPROVING THE QUALITY OF HUMAN RESOURCES
}

\author{
Ningrum Nadiya Lifa*, Utami Hamidah Nayati, Abdillah Yusri \\ Department of Business Administration, Faculty of Administrative Science, \\ University of Brawijaya, Indonesia \\ *E-mail: nadiyalifaningrum@gmail.com
}

\begin{abstract}
The diversity of Indonesia's tourism is reflected in the natural and cultural tourism that has the potential to be offered to domestic and foreign tourists. With such great potential, longterm management is needed to maximize tourism development. This study aimed to reveal the implementation of Community Development and Knowledge Sharing in Improving the Quality of Human Resources, as well as any factors that affect the increase of tourism potential in Banyuwangi. Qualitative approach was used in this research to know more deeply about the phenomenon that occurs and find solutions in the management of tourism development.
\end{abstract}

\section{KEY WORDS}

Community development, knowledge sharing, human resources quality, community based tourism, Banyuwangi.

Tourism is one sector that has an important role in improving the economy of a country. The development of tourism can bring a broad impact for the economy in an area because tourism includes a variety of potential economic efforts that can be an economical generator in a city, province, and tourist destination areas (Goeldner et al., 2000). The large number of foreign and domestic tourists coming to a region becomes an opportunity for the tourism sector. Tourism products in Indonesia are mostly in the form of natural tourism presented with the concept of ecotourism. The ecotourism concept is considered appropriate with the current tourism industry that is popular among tourists. The concept of ecotourism does not only present the fun in a tourism activity, but also becomes a space of education for tourists about the importance of environmental sustainability.

The increasing number of tourists visiting Banyuwangi as a tourist destination requires direct involvement of local communities and private parties to actively participate in their development. This is in line with the concept of community development that comes side by side with the concept of ecotourism. Community Development is a development program for a community as an effort to develop a sustainable and active community condition based on the principles of social justice and mutual respect (Zubaidi, 2007). The concept of Community Development is the answer to the critics of the weakness of community empowerment at the low or local level. Empowering local communities to be able to sustain the development of the era while still maintaining the locality is one important thing.

In the process of empowering local elements through the community development, the activity of knowledge or insight exchange through interaction will occur. This exchange is then referred as Knowledge Sharing. Hansel and Avital (2005) suggested that Knowledge Sharing is a behavior owned by everyone in sharing his or her knowledge and experience with others voluntarily. Knowledge sharing can change the mindset or way of thinking of communities or groups to grow because of new insights that encourage members of tourism groups to think and act. An important point in the effectiveness of the implementation of knowledge sharing can be seen from the way of the organization in building a knowledge sharing culture within the organization or group. Through knowledge sharing, knowledge can be spread, implemented, and developed. Sharing will allow individuals within the organization to think creatively and critically (Lindsey, 2006), so that in the end it can generate new knowledge that is useful to improve the quality of human resources of the 
members of the group. The challenges faced are how to prepare the ability and manage tourism well, and what factors are supporting and hindering tourism development.

\section{LITERATURE REVIEW}

Community Development is «an effort to develop sustainable and active community conditions based on the principles of social justice and mutual respect» (Zubaedi, 2007). Communities will actively participate on the basis of their own consciousness because the process of sustainable development will not be able to run without the active participation of the community. A regional tourism development requires the support of local community, which is not only as an object but also as a subject in every activity to develop local tourism. Community-based tourism can make local tourism as a local wisdom, community responsibility to the living environment, and the preservation of residential areas by participating in every activity.

The concept of community-based tourism development for the first time was popularized by Murphy. According to Murphy (1985), tourism products and consumers must be visible to local communities who are often very aware of the impact of tourism. There will be community activities undertaken on the basis of problem solving in the community. The problems that arise in rural or urban communities are related to development issues. BUNDER group is a form of community formed by the people around Bangsring Beach in the concept of community-based tourism development. Community activities were carried out by empowering the community to change the mindset of the surrounding community in developing tourism and preparing human resources or skills of the group members. Thus, it can improve the quality of human resources in tourism development. Community Based Tourism is a concept that is used as tools in community development (Community Development) in the field of tourism. This is in line with Suansri (2003) «Community Based Tourism as a tourism that takes into account environmental, social, and cultural sustainability aspects».

Knowledge sharing becomes one of the important things both in business and nonbusiness organization. This happens because all human activities are organizing activities. Each organization has members working based on his or her knowledge. Therefore, managing knowledge is the same as managing members (Setiarso et al., 2009). Knowledge sharing provides an opportunity to members of the organization to share their knowledge such as techniques, ideas, and experiences they have to other group members. In the implementation of knowledge sharing in order to provide benefits in the long term, an organization must be aware of the existence of workers, knowledge creation, and users so that knowledge sharing can run effectively and the quality of human resources expected in the organization or group can be increased so it can bring new innovations in maintaining the sustainability of the group. In tourism, Knowledge Sharing can support the running of tourism development activities. Knowledge sharing becomes an activity to increase knowledge, experience, or communication with each other among group members. This is supported by the opinion of Riddings in Nezakati (2015) that in the tourism industry, knowledge sharing is the main point used in communication by exchanging experiences with members of tourism managers and tourists.

Tourism human resources according to the national conception is the tourism human resource as a regional asset that has the standard of ability (knowledge and skill) according to the competence of their expertise that is recognized and accepted by the tourism community and based on the high dedication of nationality so that it has competitive value and able to compete on a national and international scale. Every tourist destination is required to be able to improve the quality of human resources because actually the quality of human resources is what is believed to determine the quality of tourism products and services directly. 


\section{METHODS OF RESEARCH}

This research used descriptive qualitative method. Qualitative research intended to understand or explain the phenomena or problems that exist and experienced by the subject of research (Sugiyono, 2008). The focus of this research were the implementation of Community Development in the BUNDER group as improving the quality of human resources, the implementation of Knowledge Sharing in the BUNDER group as an improvement of the quality of human resources as well as any supporting and inhibiting factors in the development of Bangsring Beach tourism, Banyuwangi. The key informants in this research were the Chairman of the BUNDER group, the vice chairman of the BUNDER group, and the fishermen. Meanwhile, the representatives of the Tourism Department provide additional information. The researcher also made observations and went directly to the field, so the observations made were participant or involvement observation (Salim, 2006). For data validity test, the researcher used triangulation method.

\section{RESULTS AND DISCUSSION}

The implementation of Community Development in the BUNDER group was very useful to improve the ability of BUNDER group in developing the tourism of Bangsring Beach and overcome the problems of the Bangsring Fishermen group. In this case, community development can help develop community's human resources because in this tourism local people play an active role in every tourism process, so that all policies and activities were organized by BUNDER group. Community development was embodied in the formation of the BUNDER group which was the first movement to raise awareness of local community. The BUNDER group was a group formed to develop the community, to increase participation, and to change the people's mindset that become destructors in the past to be preservers today to improve their region. The establishment of a community or group of BUNDER was a proof of implementation in community development to develop the community to be more developed in taking advantage of the natural potential of the region and also to better improve the ability of local community in developing tourism. The participation was always emphasized to the local community so that the local community (BUNDER group) is all involved and participate directly in managing tourism. In addition, the existence of tourism with the concept of ecotourism was a form of community development to make members of the group to further develop the capabilities in developing tourism while maintaining and preserving the surrounding environment.

Implementation of Knowledge Sharing in this BUNDER group has been applied and indeed was needed to be applied from the beginning of BUNDER group formation. The education level of Bangsring community which was mostly low and the habits of slum fishing community, initially became an obstacle in the process of tourism development, but the BUNDER group did not make it a constraint, but a challenge to change it. Knowledge Sharing activities in the BUNDER group were evidenced in meetings or regular meetings held once every 3 months. In the meeting, group members can discuss and exchange knowledge or experience and there was also an evaluation that made the marking better for the future. Apart from meetings, BUNDER group also shared knowledge by establishing mutual visit that was commonly called door to door to the house of group members or to the house of the group leader. In visiting, members of the BUNDER group shared their knowledges or experiences. Knowledge Sharing was also not only applied in the BUNDER group but also in the Tourism Department, which provided training or workshops on foreign language (English) training, guide training, and marine science training because tourism that was formed in Bangsring area was marine tourism. Foreign languages were needed for tourism activities because tourist guests who come were not only from domestic but also from abroad. Since Bangsring community education was low and education on language was also less, so foreign language training was chosen to prepare human resources and improve the quality or ability of human resources group BUNDER in serving foreign tourists. 
The supporting factors in the process of tourism development of Bangsring Beach were managed by the BUNDER group that was the tourism potential owned by Bangsring Beach. The potential owned by Bangsring Beach can indeed be the attraction of tourists, the potential of this tourism had begun to appear when the local community began to improve the condition of marine ecology that has been destroyed. With the community development and the existence of knowledge sharing in developing this tourism, it could make the tourism as an attraction for the tourists. There was also a support from local government in tourism development. Meanwhile, the inhibiting factors that were found were the lack of capabilities possessed by the group, transportation access was not maximized.

\section{CONCLUSION}

Tour manager was a new job for some people in Bangsring Village because the potential in the form of beach beauty can attract tourists to visit. This was what made Bangsring Village people have to learn how to manage and develop tourism on an ongoing basis. To improve the quality of human resources, BUNDER group should always increase their community participation and always apply knowledge sharing culture in every activity in their group. However, the BUNDER group should be able to get closer to the local people who have not joined the BUNDER group yet. Due to the increasing participation and the level of awareness of local people in managing tourism, the development of tourism could run according to organizational or group goals and could survive in the long term. With the existence of community development, knowledge sharing, and support of the local government, the tourism potential should be managed maximally and better in the future.

\section{REFERENCES}

1. Goeldner, Charles R., J.R. Brant Ritchie, Robert W. Mclntosh. 2000. Tourism: Principles, Practise, Philosophies, Eight Edition. John Wiley and Sons, Inc.

2. Hansel, S., and Avital, M. 2005. "Share and Share a like: The Social and Technological Influences on Knowledge Sharing Behavior." Sprouts: Working Papers on Information Environment, System and Organizations 5(1): 1-19.

3. Lindsey, Tim dkk. 2006. Hak Kekayaan Intelektual. Bandung: PT Alumni.

4. Murphy, P.E. 1985. Tourism: A Community Approach. London: Methuen.

5. Nezakati, Hossein (2015). Review of Social Media Potential on Knowledge Sharing and collaboration in Tourism Industry. Global conference on Business \& social science Kuala Lumpur. Page 120-125

6. Salim, Agus. 2006. Teori dan Paradigma Penelitian Sosial. Yogyakarta: Tiara Wacana

7. Setiarso, B.dkk. 2009. Penerapan Knowledge Management pada organisasi, Graha IImu, Yogyakarta.

8. Suansri, Potjana. 2003. Community Based Tourism Handbook. Thailand: Rest Project

9. Sugiyono, 2008. Metode Penelitian Kuantitatif, Kualitatif, R\&D. Bandung: Alfabeta

10. Zubaedi. 2007. Wacana Pembangunan Alternatif: Ragam Perspektif Pengembangan dan Pemberdayaan Masyarakat. Yogyakarta: Ar-Ruzz Media. 